\title{
Vegetative rescue potential of Brazil nut through epicormic shoots on detached branches
}

\author{
Jônathan Brito Fontoura CONCEIÇÃO ${ }^{1 *} \mathbb{C}$, Sidney Alberto do Nascimento FERREIRA², \\ Natália Neves de LIMA ${ }^{3}$ \\ I Instituto Nacional da Mata Atlântica (INMA), Av. José Ruschi 4, Santa Teresa, CEP 29650-000, Espírito Santo, Brazil \\ 2 Instituto Nacional de Pesquisas da Amazônia (INPA), Coordenação de Biodiversidade (COBIO), Av. André Araújo 2936, CEP 69067-375, Manaus, AM, Brazil \\ 3 Instituto Nacional de Pesquisas da Amazônia (INPA), Programa de Pós-Graduação em Agricultura no Trópico Úmido (PPG-ATU), Av. André Araújo 2936, \\ CEP 69067-375, Manaus, AM, Brazil \\ * Corresponding author: Johnbrito.jbfc@gmail.com; (D) https://orcid.org/0000-0002-2017-4126
}

\begin{abstract}
Obtaining juvenile material may favor the clonal propagation of Brazil nut, Bertholletia excelsa. We aimed to assess the emission of epicormic shoots on detached branches of Brazil nut trees as a function of the mother tree and branch diameter, in order to provide juvenile material for use in clonal multiplication. The experimental design was completely randomized in a 6 (mother trees) x 3 (stem diameter: < 20 20-40 and 40-80 mm) factorial design, with four replicates. Every five days the number of shoots emitted was counted and the sprouting speed index and average sprouting time were calculated. The number of epicormic shoots and the sprouting speed index were dependent on the interaction between mother tree and branch diameter. Branches with larger diameter $(20-40$ and $40-80 \mathrm{~mm}$ ) showed higher potential for obtaining propagules for use in Brazil nut clonal multiplication (cutting, grafting and in vitro cultivation).
\end{abstract}

KEYWORDS: Lecythidaceae, asexual reproduction, juvenility, clonal forestry

\section{Potencial de resgate vegetativo da castanha-do-brasil a partir de brotações epicórmicas de ramos destacados}

\section{RESUMO}

A obtenção de material juvenil pode favorecer a propagação clonal da castanha-do-Brasil, Bertholletia excelsa. Objetivou-se avaliar a emissão de brotaçóes epicórmicas em ramos destacados de castanheira, em função da planta-matriz e do diâmetro dos mesmos, visando disponibilizar material juvenil que possa ser utilizado na multiplicação clonal da espécie. O delineamento experimental foi inteiramente casualizado, em esquema fatorial 6 (plantas-matriz) x 3 (diâmetros do ramo: <20, 20-40 e 40-80 $\mathrm{mm}$ ), com quatro repetiçóes. A cada cinco dias, o número de brotos emitidos foi contado e o índice de velocidade e tempo médio de brotação foram calculados. O número de brotaçôes epicórmicas e o índice de velocidade de brotação foram dependentes da interação entre plantas-matriz e diâmetro do ramo. Ramos de maior diâmetro (20-40 e 40-80 mm) mostraram maior potencial para obtençáo de propágulos para uso na multiplicação clonal (estaquia, enxertia e cultivo in vitro) da castanha-do-Brasil.

PALAVRAS-CHAVE: Lecythidaceae, propagação assexuada, juvenilidade, silvicultura clonal

Brazil nut, Bertholletia excelsa Bonpl. is one of the most valuable trees in Amazonian terra firme forest, on account of the nutritional value of its seeds and the specie's socioeconomic and ecological importance in the region (Silva et al. 2013). Its propagation usually takes place through seeds (sexual), which presents limitations due to seed dormancy, with slow and irregular germination, along with a wide genetic variability, which results in a long time for preparing the seedlings (Müller et al. 1995). The multiplication of selected material has been done by grafting (Müller et al. 1995), which also depends on seed germination for rootstock formation. Thus, the improvement of asexual propagation through the use of adult-tree juvenile propagules may contribute to the clonal silviculture of the species by facilitating access to quality material (e.g. regularity and high fruit yield).

Juvenile propagules can be obtained from epicormic shoots, which are stimulated by techniques such as stem coppicing, girdling and semi-girdling, in addition to the use of detached live branches (Stuepp et al. 2018). The latter technique has shown good results for epicormic-shoot 
induction in arboreal species, causing less damage to the mother plant and, in some cases, allowing better vegetative propagation (Stuepp et al. 2014). Here we aimed to assess the epicormic shoot emission on detached branches to obtain propagules for Brazil nut clonal forestry.

We used branches from six adult 23-year-old trees with over $40 \mathrm{~cm}$ diameter at breast height (DBH) located in a 52ha private reserve [Reserva Particular do Patrimônio Natural Dr. Daisaku Ikeda (0306 '27.67'S, 59054'41.16”W)], in Manaus, Amazonas state, Brazil. The vegetation is secondary forest. The climate is tropical humid to super humid, with annual mean temperature and rainfall around $26.7^{\circ} \mathrm{C}$ and $2419 \mathrm{~mm}$, respectively, and $87.5 \%$ mean relative humidity (Ribeiro 1976).

Each tree was climbed using rappel to access the lower canopy, where five branches were cut off. On the ground, they were sectioned into stems and grouped into thre diameter categories (<20 mm; 20-40 mm; 40-80 mm). All stems had a standard length of $40 \mathrm{~cm}$. They were then packed in raffia bags containing moistened newspaper and transported to the seedling nursery.
The experiment was carried out in a seedling nursery at Instituto Nacional de Pesquisas da Amazônia (INPA) ( $3^{\circ} 08^{\prime}$ S, $\left.60^{\circ} 01^{\prime} \mathrm{W}\right)$, in Manaus, over-shadowed with $70 \%$ shading screen, floor lined with pebbles, and irrigated by intermittent misting controlled by a evaporation scale (Miranda 1983).

Prior to the experiment, the upper tips of the stems were dipped in heated paraffin, to reduce water loss. They were then arranged in plastic boxes $(43 \mathrm{~cm} \times 63 \mathrm{~cm} \times 18 \mathrm{~cm})$ containing sand, into which the stems were positioned vertically, with 10 $\mathrm{cm}$ buried into the substrate (Figure 1a). The stems remained in the boxes for 90 days. We used a 6 (mother tree) x 3 (stem diameter) completely randomized factorial design, with four replicates, each containing 5 stems.

The number of shoots was counted every five days for three months. At the end of this period, we measured the diameter and length of 20 randomly chosen shoots per mother tree and diameter catogory. For the purpose of statistical analysis, shoot counts obtained up to 45 days (average period of greatest sprout emission, Figure 1b) were considered and, from these, the sprouting speed index [adapted from Maguire (1962)] and average sprouting time [adapted from Labouriau (1983)] were calculated. The variables were square-root transformed for

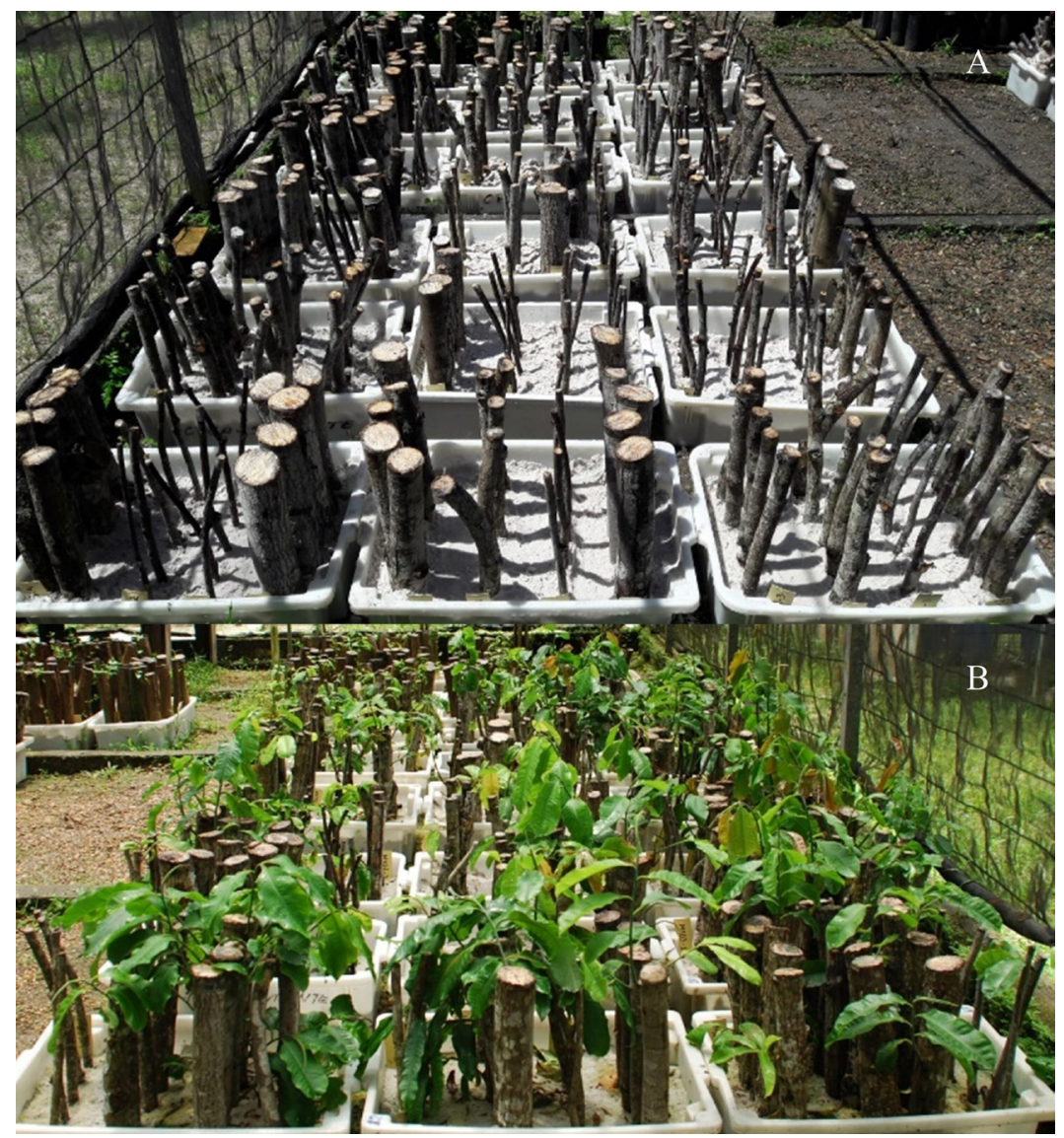

Figure 1. Images showing the experiment setup for the evaluation of epicormic shoot emission on branch stems of Brazil nut (Bertholletia excelsa) trees in seedling nursery conditions, with intermittent misting system. A - at the time of installation; B - after 48 days. This figure is in color in the electronic version. 
normalization, and analyzed with two-way ANOVAs, followed by a Tukey test for paired mean comparison $(\mathrm{p}<0.05)$, using the ASSISTAT 7.7 program (Silva and Azevedo 2016).

Shoot emission varied among mother trees and diameter categories (Figures 2). The first shoots sprouted from 20-40$\mathrm{mm}$ diameter stems of mother-tree 2 (Figure 2b) at 10 days. At 15 days, sprouting started on the other two diameter categories of mother-tree 2 , as well as on all diameter categories of mother-trees 3 (Figure 2c) and 5 (Figure 2e). Sprouting onset on stems from the other mother-trees (Figures $2 a$, $d$ and f) ranged from 20 to 25 days. Sprouting tended to stabilize between 35 and 45 days, indicating that this was the period of maximum epicormic-shoot sprouting potential for all mother trees and diameter categories. Therefore, statistical analysis was made with data obtained up to 45 days.

Number of shoots and sprouting speed index showed significant interaction effect between mother tree and stem diameter. Stems of $40-80 \mathrm{~mm}$ had the largest number of shoots, though the values did not differ significantly from those of $20-40-\mathrm{mm}$ stems in most mother trees (Table 1). Stems with $<20 \mathrm{~mm}$ generally had significantly less shoots
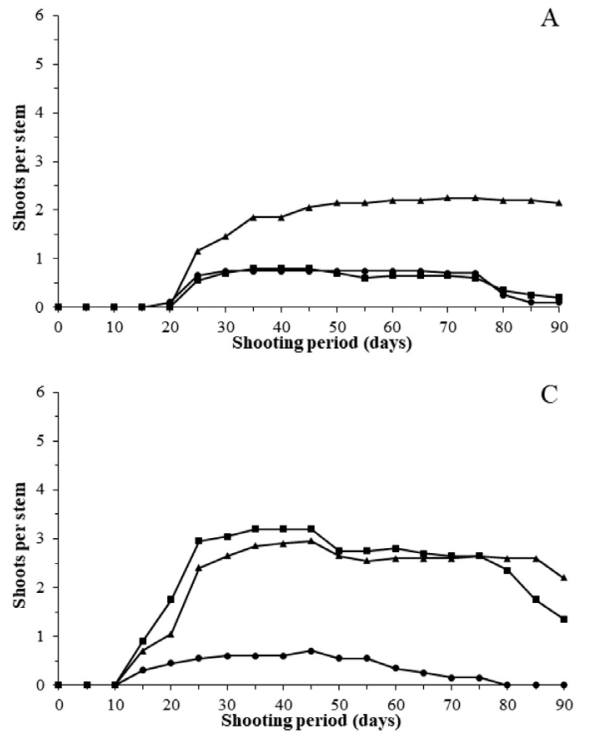

\section{,}
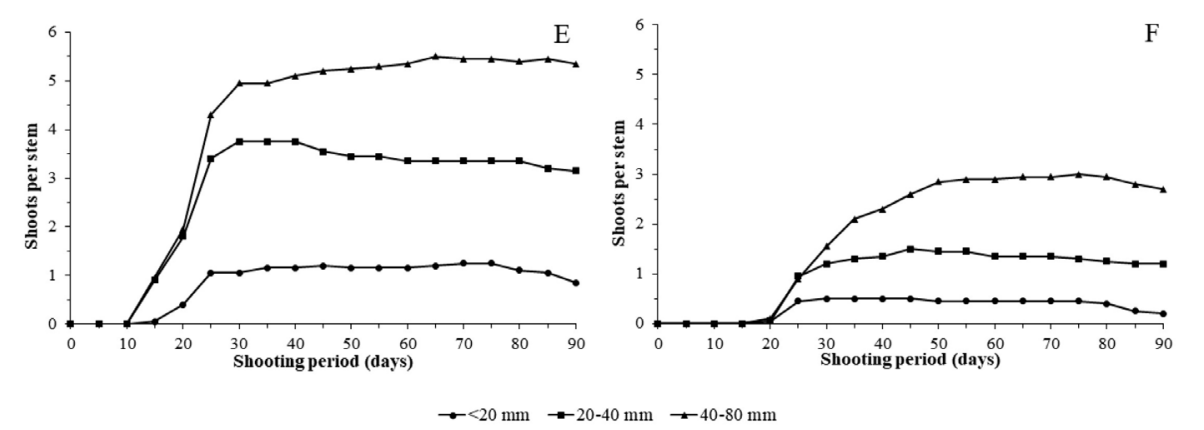

then the thicker stems, usually one less per stem. The highest average number of shoots per stem was observed for the 4080 -mm stems of mother tree 5 (5.2), followed by averages of 3.0 for the same diameter category of mother trees 2 and 3 .

The sprouting speed index mirrored the behavior of the number of sprouts per stem, showing higher values for the thicker stems, especially the 40-80-mm category (Table 1). Mother tree 5 had the highest values, though not significantly different from mother trees 2 and 3 .

Average sprouting time did not show interaction effect among the factors. It varied significantly among mother trees (Table 1), but not among diameter categories. Mother tree 2 showed the shortest average sprouting time (19.5 days), followed by mother trees 5 (22.5) and 3 (23.7), which did not differ significantly. After 90 days, the epicormic shoots had an overall average diameter of $4.0 \pm 0.19 \mathrm{~mm}$ and length of $7.9 \pm$ $0.83 \mathrm{~cm}$, with little variation among mother trees (Figure 3).

The onset of epicormic shoot emission in the three diameter categories took place between 10 and 25 days for all mother trees, and was lower than that observed for Ilex paraguariensis and Eucalyptus cloeziana, which emitted first
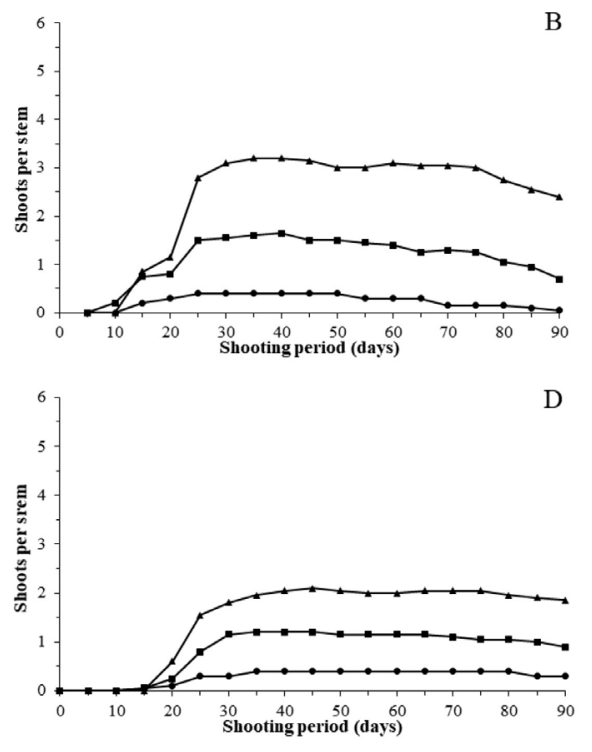

$\rightarrow<20 \mathrm{~mm} \rightarrow-20-40 \mathrm{~mm} \rightarrow-40-80 \mathrm{~mm}$

Figure 2. Evolution of the five-day average number of epicormic shoots emitted by branch stems of each of six Brazil nut (Bertholletia excelsa) trees over a 90-day period in seedling nursery conditions, with intermittent misting system. Data are plotted for each of three stem-diameter categories. A - mother tree $1 ; B-$ mother tree $2 ; \mathrm{C}$ - mother tree $3 ; \mathrm{D}$ - mother tree $4 ; \mathrm{E}$ - mother tree $5 ; \mathrm{F}$ - mother tree 6 . 
Table 1. Number of epicormic shoots, sprouting speed index and average sprouting time for detached branches of three diameter categories from each of six Brazil nut (Bertholletia excelsa) trees, after 45 days in seedling nursery conditions, with intermittent misting system.

\begin{tabular}{|c|c|c|c|c|c|c|c|}
\hline \multirow{2}{*}{$\begin{array}{l}\text { Stem diameter } \\
(\mathrm{mm})\end{array}$} & \multicolumn{7}{|c|}{ Mother tree } \\
\hline & 1 & 2 & 3 & 4 & 5 & 6 & Mean \\
\hline \multicolumn{8}{|c|}{ Number of shoots } \\
\hline$<20$ & $0.8 \mathrm{aB}$ & $0.5 \mathrm{aC}$ & $0.7 \mathrm{aB}$ & $0.4 \mathrm{aB}$ & $1.2 \mathrm{aB}$ & $0.6 \mathrm{aB}$ & 0.7 \\
\hline $20-40$ & $0.8 \mathrm{bB}$ & $1.5 \mathrm{bB}$ & $3.2 \mathrm{aA}$ & $1.2 \mathrm{bA}$ & $3.6 \mathrm{aA}$ & $1.5 \mathrm{bA}$ & 2.0 \\
\hline $40-80$ & $2.1 \mathrm{bA}$ & $3.2 \mathrm{abA}$ & $3.0 \mathrm{bA}$ & $2.1 \mathrm{bA}$ & $5.2 \mathrm{aA}$ & $2.6 \mathrm{bA}$ & 3.0 \\
\hline Mean & 1.2 & 1.7 & 2.3 & 1.2 & 3.3 & 1.6 & \\
\hline $\mathrm{CV}(\%)=20.41$ & & \multicolumn{2}{|c|}{$F_{M}=12.46^{* *}$} & \multicolumn{2}{|c|}{$F_{D}=73.84^{* *}$} & \multicolumn{2}{|c|}{$F_{M \times D}=2.09^{*}$} \\
\hline \multicolumn{8}{|c|}{ Sprouting speed index (shoot day ${ }^{-1}$ ) } \\
\hline$<20$ & $0.03 \mathrm{aA}$ & $0.02 \mathrm{aB}$ & $0.04 \mathrm{aB}$ & $0.02 \mathrm{aB}$ & $0.05 \mathrm{aB}$ & $0.02 \mathrm{aB}$ & 0.03 \\
\hline $20-40$ & $0.03 \mathrm{bA}$ & $0.09 \mathrm{abA}$ & $0.16 \mathrm{aA}$ & $0.05 \mathrm{bAB}$ & $0.18 \mathrm{aA}$ & $0.05 \mathrm{bAB}$ & 0.09 \\
\hline $40-80$ & $0.07 \mathrm{bA}$ & $0.15 \mathrm{abA}$ & $0.13 a b A$ & $0.08 \mathrm{bA}$ & $0.24 \mathrm{aA}$ & $0.09 \mathrm{bA}$ & 0.13 \\
\hline Mean & 0.04 & 0.09 & 0.11 & 0.05 & 0.15 & 0.05 & \\
\hline $\mathrm{CV}(\%)=23.80$ & & \multicolumn{2}{|c|}{$F_{M}=14.34^{* *}$} & \multicolumn{2}{|c|}{$F_{D}=56.42^{* *}$} & \multicolumn{2}{|c|}{$F_{M \times D}=2.12^{*}$} \\
\hline \multicolumn{8}{|c|}{ Average sprouting time (days) } \\
\hline$<20$ & 25.1 & 18.3 & 25.5 & 25.6 & 23.0 & 24.9 & 23.7 \\
\hline $20-40$ & 26.9 & 17.9 & 22.0 & 25.7 & 21.0 & 29.5 & 23.8 \\
\hline $40-80$ & 29.1 & 22.2 & 23.5 & 25.9 & 23.6 & 31.3 & 26.0 \\
\hline Mean & $27.0 a b$ & $19.5 d$ & $23.7 \mathrm{bcd}$ & $25.7 a b c$ & $22.5 \mathrm{~cd}$ & $28.6 a$ & \\
\hline $\mathrm{CV}(\%)=7.55$ & & \multicolumn{2}{|c|}{$F_{M}=10.10^{* *}$} & \multicolumn{2}{|c|}{$F_{D}=3.13^{\mathrm{ns}}$} & \multicolumn{2}{|c|}{$F_{M \times D}=0.80^{\text {ns }}$} \\
\hline
\end{tabular}

$\mathrm{CV}=$ coefficient of variation; $\mathrm{F}_{\mathrm{M}^{\prime}} \mathrm{F}_{\mathrm{D}^{\prime}} \mathrm{F}_{\mathrm{M} \mathrm{D}}=\mathrm{F}$-test value for mother tree, diamete and their interaction; ${ }^{*} \mathrm{p} \leq 0.05,{ }^{* *} \mathrm{p}<0.01$; ns $=$ not significant. Means followed by the same lowercase letter in the row and uppercase in the column do not differ significantly from each other according to the Tukey test $(p<0.05)$.

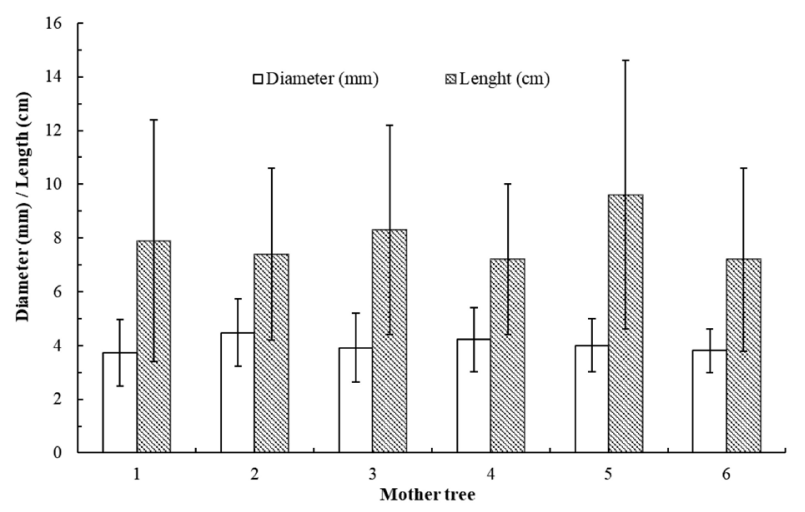

Figure 3. Diameter (white) and length (grey) of epicormic shoots emitted by branch stems of each of six Brazil nut (Bertholletia excelsa) trees after 90 days in seedling nursery conditions, with intermittent misting system. Columns represent the mean and bars the standard deviation.

epicormic shoots at 30 and 40 days, respectively (Almeida et al. 2007; Wendling et al. 2013).

The shoot-emission potential in the Brazil-nut branch stems decreased after emission stabilization at about 45 days. Wendling et al. (2013) and Nascimento et al. (2018) also reported a reduction in the number of shoots in pruned branches of erva-mate (Ilex paraguariensis) following 50 days. The decrease in epicormic-shoot emission may be linked to the exhaustion of nutritional reserves in the Brazil-nut branch stems. Reserves might have been directed towards the first emitted shoots, causing later drying of newly formed shoots and contributing to their declining number. The drying of newly formed shoots occurs when they turn into liquid carbohydrate exporters to more vigorous shoots with mature leaves (Meier et al. 2012).

Dias et al. (2015) and Stuepp et al. (2016) found that diameters $\leq 4 \mathrm{~mm}$ provided the highest rooting percentage in cuttings from epicormic shoots of Anadenanthera macrocarpa and Ilex paraguariensis, respectively. Our mean shoot lengths were similar to those of epicormic shoots of $I$. paraguariensis trees submitted to a high intensity of branch pruning $(8.9 \mathrm{~cm}$ at 90 days) (Santin et al. 2008).

In our study, the number of epicormic shoots and the sprouting speed index were dependent on the mother tree and branch diameter association. The number of shoots and the sprouting speed index decreased as stem diameter diminished. The higher shoot yield on thicker branch stems (20-40 and 40-80-mm diameters) favored obtaining juvenile propagules with potential to be used in the clonal multiplication (cutting, grafting or in vitro cultivation) of Brazil-nut tree, and require further assessment.

\section{ACKNOWLEDGMENTS}

We thank Coordenação de Aperfeiçoamento de Pessoal de Nível Superior (CAPES) for the master scholarship for the first and third author, and the Instituto Soka - CEPEAM for its support and access to the study material. 


\section{REFERENCES}

Almeida, F.D.; Xavier, A.; Dias, J.M.M. 2007. Propagação vegetativa de árvores selecionadas de Eucalyptus cloeziana F. Muell. por estaquia. Revista Árvore, 31: 445-453.

Dias, P.C.; Xavier, A.; Oliveira, L.S.; Félix, G.A.; Pires, I.E. 2015. Resgate vegetativo de árvores de Anadenanthera macrocarpa. Cerne, 21: 83-89.

Labouriau, L.G. 1983. A Germinação das Sementes. Organização dos Estados Americanos, Washington, 174p.

Maguire, J.D. 1962. Speed of germination-aid in selection and evaluation for seedling emergence and vigor. Crop Science, 2: 176-177.

Meier, A.R.; Saunders, M.R.; Michler, C.H. 2012. Epicormic buds in trees: a review of bud establishment, development and dormancy release. Tree Physiology, 32: 565-584.

Miranda, R.M. 1983. Irrigação por Nebulização Intermitente para Enraizamento de Estacas de Guaraná. Empresa Brasileira de Pesquisa Agropecuária, Manaus, 34p.

Müller, C.H.; Figueiredo, F.J.C.; Kato, A.K.; Carvalho, J.E.U.; Stein, R.L.B.; Silva, A.B. 1995. A Cultura da Castanha-do-Brasil. Empresa Brasileira de Pesquisa Agropecuária, Brasília, 65p.

Nascimento, B.; Sá, A.C.S.; Lemos, L.B.; Rosa, D.P.; Pereira, M.O.; Navroski, M.C. 2018. Three epicormic shoot techniques in $I$. paraguariensis mother trees and its cutting according to the material rejuvenation degree. Cerne, 24: 240-248.

Ribeiro, M.N.G. 1976. Aspectos climatológicos de Manaus. Acta Amazonica, 8: 229-233.

Santin, D.; Wendling, I.; Benedetti, E.L.; Brondani, G.E.; Reissmann, C.B.; Morandi, D.; Roveda, L.F. 2008. Poda e anelamento em erva-mate (Ilex paraguariensis) visando à induçáo de brotaçōes basais. Pesquisa Florestal Brasileira, 56: 97-104.

Silva, A.A.; Santos, M.K.V.; Gama, J.R.V.; Noce, R.; Leão, S. 2013 Potencial do extrativismo da castanha-do-pará na geração de renda em comunidades da Mesorregião Baixo Amazonas, Pará. Floresta e Ambiente, 20: 500-509.

Silva, F.A.S.; Azevedo, C.A.V. 2016. The Assistat Software Version 7.7 and its use in the analysis of experimental data. African Journal of Agricultural Research, 11: 3733-3740.

Stuepp, C.A.; Bitencourt, J.; Wendling, I.; Koehler, H.S.; ZuffellatoRibas, K.C. 2016. Indução de brotaçóes epicórmicas por meio de anelamento e decepa em erva-mate. Ciência Florestal, 26: 1009-1022.

Stuepp, C.A.; Wendling, I.; Xavier, A.; Zuffellato-Ribas, K.C. 2018. Vegetative propagation and application of clonal forestry in Brazilian native tree species. Pesquisa Agropecuária Brasileira, 53: 985-1002.

Stuepp, C.A.; Zuffellato-Ribas, K.C.; Wendling, I.; Koehler, H.S.; Bona, C. 2014. Vegetative propagation of mature dragon trees through epicormic shoots. Bosque, 35: 337-345.

Wendling, I.; Brondani, G.E.; Biassio, A.; Dutra, L.F. 2013. Vegetative propagation of adult Ilex paraguariensis trees through epicormic shoots. Acta Scientiarum. Agronomy, 35: 117-125.

RECEIVED: 05/11/2019

ACCEPTED: 09/07/2020

ASSOCIATE EDITOR: Antonio R. Fernandes 